\title{
26. DATA REPORT: AMINOSTRATIGRAPHIC ANALYSIS OF MOLLUSK SPECIMENS: CAPE MAY COAST GUARD STATION BOREHOLE ${ }^{1}$
}

\author{
John F. Wehmiller ${ }^{2}$
}

\section{INTRODUCTION}

Amino acid racemization (AAR) in fossil calcareous organisms has been used for a variety of Quaternary stratigraphic and geochronologic applications, including studies of coastal, shelf, and deep marine carbonate fossils (Miller and Brigham-Grette, 1989; Wehmiller, 1993). The present study was undertaken to compare AAR data from mollusks in the Cape May borehole (Ocean Drilling Program [ODP] Leg 150X) with data obtained from other sites in the region (Groot et al., 1990), including a nearby borehole drilled at the Cape May County Airport in 1988 (Lacovara, 1990; Groot, 1991; Newell et al., 1995). AAR data from shells at $98 \mathrm{ft}$. $(29.9 \mathrm{~m})$ below land surface at the Airport site yielded an age estimate of early Pleistocene or late Tertiary (K.J. Lacovara and J.F. Wehmiller, unpubl. data; Groot, 1991), an age much greater than expected based on other studies (Newell et al., 1995). Consequently, the major purpose of the aminostratigraphic analysis of the samples from the newly drilled ODP Leg150X Cape May site is to determine the reproducibility of the results obtained from the Airport borehole. Figure 1, redrawn from Groot et al. (1990), shows the location of mid-Atlantic sites for which aminostratigraphic data are available.

\section{SAMPLES AND METHODS}

A Mulinia-bearing unit was encountered at a depth of approximately $85-90 \mathrm{ft}(25.9-27.4 \mathrm{~m})$ below land surface in the Leg150X Cape May Coast Guard station hole (see complete stratigraphic section in Miller, et al. [1996]). Mulinia were obtained from this unit by washing and sieving with distilled water. After air-drying, shells for analysis were weighed, cleaned with gentle mechanical abrasion, and rinsed with dilute $\mathrm{HCl}$ and $\mathrm{NH}_{4} \mathrm{OH}$. Samples were then dissolved in an appropriate amount of concentrated $\mathrm{HCl}$ to bring the final solution to $6 \mathrm{~N}$ for acid hydrolysis. Because of the small size of the samples (all less than $2 \mathrm{mg}$ ), the method of acid hydrolysis was modified from normal procedures to assure that the hydrolysis solution remained as a liquid in the bottom of the hydrolysis tube. This modified hydrolysis procedure was not used in previous analyses of equally small Mulinia from the Airport hole (K.J. Lacovara, pers. comm., 1996), and separate experiments indicate that it is highly probable that the previous analyses were adversely affected. Because of the need to obtain a direct comparison of results from the Airport and Coast Guard holes, three samples from each of these holes were prepared and analyzed simultaneously, so that all procedures were applied in the same manner.

${ }^{1}$ Miller, K.G., and Snyder, S.W. (Eds.), 1997. Proc. ODP, Sci. Results, 150X: College Station, TX (Ocean Drilling Program).

${ }^{2}$ Department of Geology, University of Delaware, Newark, DE 19716, U.S.A. jwehm@udel.edu
Only whole valves of Mulinia were analyzed in the present study, to minimize the chances of obtaining results for specimens reworked from older units. The fragile nature of these valves, and the finegrained sediments themselves, are interpreted as indicators of a lowenergy depositional environment with little or no reworking. No articulated shells were seen in the washed sediments.

After hydrolysis, sample solutions were dried under a stream of nitrogen and then redissolved in $\mathrm{pH} 2$ buffer for high-pressure liquid chromatographic analysis (HPLC) of the D-alloisoleucine/L-isoleucine values (hereafter referred to as A/I, a ratio that grows from 0.0 in modern samples to approximately 1.3 at equilibrium [Wehmiller, 1993]). Because of the small sample sizes, hydrolyzates were analyzed only once instead of the usual two or three times. A/I values were measured using either peak area integration or peak height measurements. Sample numbers, depths, and A/I values are summarized in Table 1. Uncertainties are estimated from prior experience with Mulinia analyses (York et al., 1989), rather than from multiple chromatograms of each sample hydrolyzate.

\section{DISCUSSION}

The results presented in Table 1 are interpreted to indicate that the Mulinia samples from the two sites fall within the same aminozone; therefore, they are the same age within the normal resolving power of the method. For purposes of general discussion, the grand mean for the six shells from both holes is taken to be approximately $0.60 \pm$ 0.05 . This mean value is on the lowest end of the range of values $(0.75 \pm 0.15)$, obtained in the previous study of the Airport hole (K.J. Lacovara and J.F. Wehmiller, unpubl. data), resulting in a somewhat younger age estimate than originally presented by Groot (1991). The higher A/I value, and the large variability, are interpreted to be consequences of the hydrolysis procedure utilized in the previous study.

A mean A/I value of 0.60 for Mulina has to be converted into an "equivalent Mercenaria" A/I value for comparison with regional coastal plain aminozones based on this frequently analyzed genus (Wehmiller et al., 1988; York et al., 1989; Groot et al., 1990). Using the equations presented by Wehmiller et al. (1988), the Mulinia A/I value of 0.60 converts to an equivalent Mercenaria A/I value of 0.86 (these conversions are based on intergeneric relationships observed at many field sites, Mulinia being a substantially slower racemizer than Mercenaria). Figure 2, redrawn from Genau et al. (1994), shows how a Mercenaria A/I value of 0.86 (plotted with a $\pm 15 \%$ uncertainty to accommodate the range of Mulinia $\mathrm{A} / \mathrm{I}$ values and the uncertainty of the intergeneric conversion) relates to the regional aminostratigraphy. The analyzed shells appear to represent either Aminozone IId or Aminozone IIe, which have been assigned to either "early Pleistocene" or "pre-Pleistocene" based upon kinetic modeling and/or local biostratigraphic information (Wehmiller et al., 1988; Groot et al., 1990). Similar aminostratigraphic ages have also been inferred for units from the mid-Atlantic continental shelf (Groot et al., 1995). A "stratigraphic test" of the combined results from the Airport and 
Figure 1. Sites in the mid-Atlantic coastal plain for which aminostratigraphic data are available. The sections at Gomez Pit, VA (Mirecki et al., 1995), and Stetson Pit, NC (York et al., 1989), are important references for the regional aminostratigraphy, because they contain multiple aminozones in observed superposition, including the aminozones found in the geomorphic units known as the Omar-Accomack and Nassawadox complexes on the Delmarva Peninsula (Fig. 2). See Groot et al. (1990) and Genau et al. (1994) for further discussion of the Delmarva units. The Cape May County Airport and Leg 150X Coast Guard holes are located near the southern end of the Cape May peninsula. Other sites in the immediate area for which substantial data are available include the Cape May Canal and Morie Pit, as well as several sites in Delaware (Groot et al., 1990; K.J. Lacovara, M.L. O'Neal, and J.F. Wehmiller, unpubl. data).

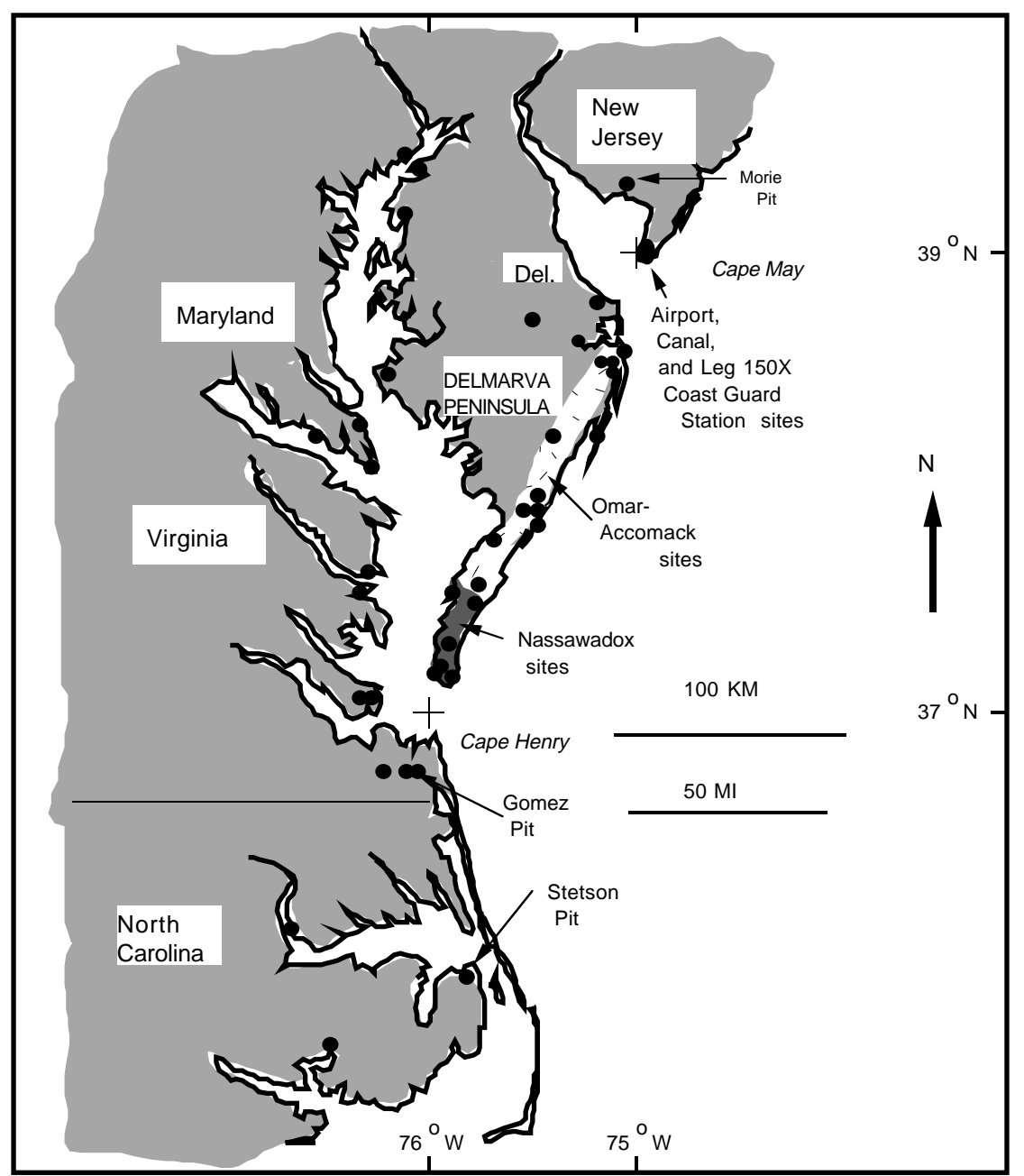

Table 1. D-alloisoleucine/L-isoleucine values determined in Mulinia from the Cape May Airport and ODP Cape May Coast Guard Station boreholes.

\begin{tabular}{clc}
\hline Sample & \multicolumn{1}{c}{ Hole/depth } & A/I \\
\hline JW95-026-a & CM 85.6ft [25.9m] & $0.61 \pm 0.02$ \\
JW95-026-b & CM 85.6ft [25.9m] & $0.54 \pm 0.02$ \\
JW95-026-c & CM 85.6ft [25.9m] & $0.62 \pm 0.02$ \\
KJL89-3-6-a & CMAP 98ft [29.8m] & $0.58 \pm 0.04$ \\
KJL89-3-6-b & CMAP 98ft[29.8m] & $0.65 \pm 0.03$ \\
KJL89-3-6-c & CMAP 98ft[29.8m] & $0.61 \pm 0.03$ \\
\hline
\end{tabular}

Notes: $\mathrm{A} / \mathrm{I}=\mathrm{D}$-alloisoleucine/L-isoleucine. $\mathrm{CM}=\mathrm{Leg} 150 \mathrm{X}$ Cape May Coast Guard Hole, CMAP = Cape May Airport Hole. All depths are below land surface.

Coast Guard holes is provided by Mercenaria results from the shallower part of the section: A/I values between 0.19 and 0.23 were obtained from Mercenaria fragments in the Airport hole (48 ft [14.6 m] below land surface) and from whole valves collected at the Cape May Canal (Lacovara, 1990). These results indicate that two aminozones are found in direct superposition in the area (see Fig. 2).

An age estimate for the Mulinia specimens analyzed here can also be obtained by direct comparison with Mulinia data from the drilled section at Stetson Pit (Dare County, NC; see Fig. 2). The Stetson Pit Mulinia clustered into three aminozones, all with A/I values lower than those measured in the southern New Jersey holes. The oldest Mulinia, with a mean A/I value of $0.48( \pm 0.06)$ from Stetson Pit were estimated to be between 0.8 and $1.3 \mathrm{Ma}$ (York et al., 1989, fig. 3). Us- ing the $0.48 \mathrm{~A} / \mathrm{I}$ value as calibration of parabolic kinetics ${ }^{1}$ (Mitterer and Kriasusakul, 1989), and compensating for temperature differences between northeastern North Carolina (Stetson Pit) and southern New Jersey suggests that the $0.60 \mathrm{~A} / \mathrm{I}$ value for the Airport and Leg 150X Cape May holes represents an age of at least 1.2 to 2.0 Ma. Optional age estimates based on different $\mathrm{A} / \mathrm{I}$ values (within the range of most probable values from each site) could be as young as $0.8 \mathrm{Ma}$ or as old as $3.0 \mathrm{Ma}$, but the estimate of 1.2 to $2.0 \mathrm{Ma}$ is considered most likely. Consequently, it is concluded that the Mulinia-bearing units found at similar depths in both the Airport and Coast Guard holes are the same unit, and that this unit is early Pleistocene in age.

\section{SUMMARY}

Aminostratigraphic analyses of fossil molluscan material from the Leg150X Cape May Coast Guard Station Borehole have been performed to determine the reproducibility of previous aminostratigraphic analyses from the Cape May County Airport Borehole. A refined analytical protocol, applied to both the Airport and Coast Guard

${ }^{1}$ Parabolic kinetics are described by the equation $\mathrm{D} / \mathrm{L}=\mathrm{k}(\mathrm{t})^{0.5}$, where $\mathrm{k}$ is a constant for a particular genus at a particular effective temperature, and $t$ is time. $\mathrm{k}$ values can be estimated with $\mathrm{D} / \mathrm{L}$ data for a chosen calibration sample, then applied to other $\mathrm{D} / \mathrm{L}$ values from the same region. Parabolic model $\mathrm{k}$ values vary about $8 \% /{ }^{\circ} \mathrm{C}$. Parabolic kinetic models form one of several approaches to interpretation of racemization kinetics, and age uncertainties because of model differences are not included in the age ranges quoted here. 


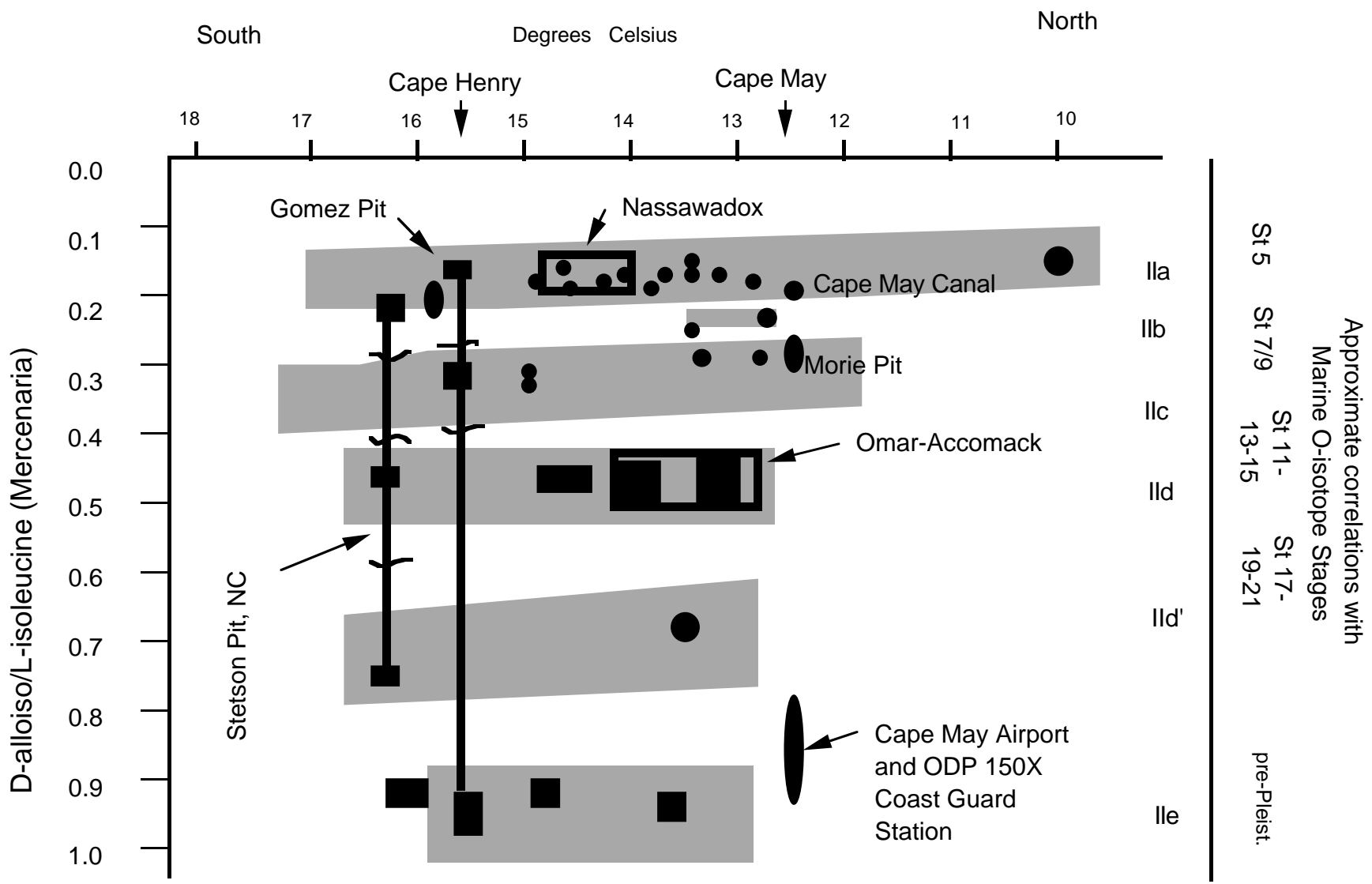

Figure 2. Mid-Atlantic regional aminostratigraphy, redrawn from Genau et al. (1994). Aminozones IIa-IIe represent clusters of D-alloisoleucine/L-isoleucine values (in Mercenaria or its equivalents), for sites shown in Figure 1. Solid circles are sites for which aminostratigraphic data exist. Superposed aminostratigraphic sections at Stetson Pit, NC, and Gomez Pit, VA are shown for reference. Aminostratigraphic data for sites within the Nassawadox and Omar-Accomack barrier complexes are shown within the rectangles that include data from Aminozones IIa and IId. The data point plotted for the Cape May County Airport and Leg 150X Coast Guard holes represents the equivalent Mercenaria value, converted from the Mulinia results in Table 1 using equations discussed in the text. Aminozone IIe represents pre-Pleistocene units of the region.

Station borehole samples, leads to the conclusion that the fossiliferous unit encountered at a depth of approximately 85-98 ft $(\sim 26-30$ $\mathrm{m})$ below land surface in these two boreholes is an early Pleistocene unit with an estimated numerical age of between 1.2 and 2.0 Ma.

\section{REFERENCES}

Genau, R.B., Madsen, J.A., McGeary, S., and Wehmiller, J.F., 1994. Seismicreflection identification of Susquehanna River paleochannels on the midAtlantic coastal plain. Quat. Res., 42:166-175.

Groot, J.J., 1991. Palynological evidence for late Miocene, Pliocene and early Pleistocene climate changes in the middle U.S. Atlantic coastal plain. Quat. Sci. Rev.,10:147-162.

Groot, J.J., Benson, R.N., and Wehmiller, J.F., 1995. Palynological, foraminiferal, and aminostratigraphic studies of Quaternary sediments from the U.S. middle Atlantic upper continental slope, continental shelf, and coastal plain. Quat. Sci. Rev., 14:17-49.

Groot, J.J., Ramsey, K.R., and Wehmiller, J.F., 1990. Ages of the Bethany, Beaverdam, and Omar formations in southern Delaware. Delaware Geol. Surv. Rept. Invest., 47:19.

Lacovara, K.J., 1990. Reference section for the Cape May Formation: Lithology, Palynology, and Amino acid data. Geol. Soc. Am. Abstr. Progr., 22:29.

Miller, G.H. and Brigham-Grette, J., 1989. Amino acid geochronology: resolution and precision in carbonate fossils. Quat. Int., 1: 111-128.

Miller, K.G., et al., 1996. Proc. ODP, Init. Repts., 150X (Suppl.): College Station, TX (Ocean Drilling Program).
Mirecki, J.E., Wehmiller, J.F., and Skinner, A.F., 1995. Geochronology of Quaternary coastal deposits, southeastern Virginia, USA. J. Coastal Res., 11:1135-1144.

Mitterer, R.M., and Kriausakul, N., 1989. Calculation of amino acid racemization ages based on apparent parabolic kinetics. Quat. Sci. Rev., 8:353357.

Newell, W.L., Powars, D.S., Owens, J.P. and Schindler, S., 1995. Surficial Geologic Map of New Jersey: Southern Sheet. Open-File Rep.-U.S. Geol. Surv., OF-95-272.

Wehmiller, J.F., 1993. Applications of organic geochemistry for Quaternary research: aminostratigraphy and aminochronology. In Engel, M.H., and Macko, S.A. (Eds.), Organic Geochemistry: New York (Plenum), 755783.

Wehmiller, J.F., Belknap, D.F., Boutin, B.S., Mirecki, J.E., Rahaim, S.D., and York, L.L., 1988. A review of the aminostratigraphy of Quaternary mollusks from United States Atlantic Coastal Plain sites. In Easterbrook, D.L. (Ed.), Dating Quaternary Sediments. Spec. Pap.-Geol. Soc. Am., 227:69-110.

York, L.L., Wehmiller, J.F., Cronin, T.M., and Ager, T.A., 1989. Stetson Pit, Dare County, North Carolina: an integrated chronologic, faunal, and floral record of subsurface coastal sediments. Palaeogeogr., Palaeoclimatol., Palaeoecol., 72:115-132.

Date of initial receipt: 25 October 1996 Date of acceptance: 4 November 1996 Ms 150XSR-320 